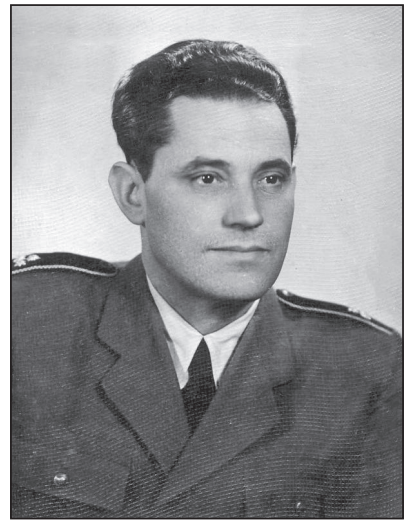

1. ábra. Kucher József löfegyverkonstruktőr

\title{
Kucher József mérnök ezredes
}

dor Műszaki Egyetem Gépészmérnöki Karán végezef Nakövetően 1936. január 4-e és 1945 szeptembere között a Danuvia Ipari és Kereskedelmi (később Danuvia Fegyver- és Lőszergyár) Rt-nél dolgozott. Fiatal mérnökként a kor legrangosabb fegyverszerkesztői (köztük Gebauer Ferenc) keze alatt dolgozott. Szakmai fejődését a Király Pállal közösen jegyzett 1939M 9 mm-es géppisztolyhoz kapcsolódó két közös szabadalom bizonyítja. Gyári munkájával párhuzamosan, megszakításokkal katonai szolgálatot (pl.: I. II. fokú pilóta- és megfigyelőképzés) is teljesített. 1948. június 1-én századosi rendfokozattal, kettős feladatra reaktiválták és a Haditechnikai Intézet Fegyver osztály állományába helyezték. Egyrészt a kutatás-fejlesztés aktuális kérdéseire kellett választ találnia, másrészt a fiatal és megbízható káderek tanításából, felzárkóztatásából is részt kellett vállalnia. Előbb szovjet anyagokat honosított (pl.: 1948M 7,62 mm-es egységes gyakorlótöltény), később felkészültsége, munkabírása alapján önálló fejlesztőmunkára kapott megbízást. A gyalogsági lőfegyver (pl.: K-l-es géppisztoly, K-ll-es géppuska) szerkesztése mellett feladatot vállalt az intézet páncélelhárítás-programjából (pl.: K-III-as gyalogsági páncélromboló) is. 1951. július 7-én kinevezték a Haditechnikai Intézet Kézifegyver osztály vezetőjének. ${ }^{1}$

A szakmai, szolgálati feladatai mellett az 1950/51-es tanévtől a Budapesti Műszaki Egyetem Hadmérnöki Kar gyalogsági fegyvertan szakelőadója volt.² 1952. február 16-án a Haditechnikai Intézet Tiszti Becsületügyi Bíróság tagjának választották. ${ }^{3}$ 1952. november 1-től a Haditechnikai Intézet Tudományos Tanácsának szavazati joggal rendelkező tagja. ${ }^{4}$ 1953. február 14-én hazaárulás vádjával letartóztatták, és április 28-án, hütlenség bűntette miatt kötél általi halálra ítélték, amelyet kegyelemből szeptember 7-én életfogytig tartó szabadságvesztésre változtattak. 1956. augusztus 17-én szabadlábra helyezték, ami után a Danuvia Szerszámgépgyárban talált munkát és menedé-

ÖSSZEFOGLALÁS: Kucher József lőfegyverkonstruktőr 1936 és 1945 között a Danuvia Fegyver- és Lőszergyárban dolgozott. 1948-ban a Haditechnikai Intézet állományába helyezték. 1953-ban koncepciós perben kötél általi halálra ítélték, amelyet életfogytig tartó szabadságvesztésre változtattak. 1956 után a Danuvia Szerszámgépgyárban talált munkát. Munkásságát az 1939M 9 mm-es és a K-I-es géppisztoly, K-II-es géppuska, a K-III-as gyalogsági páncélromboló, a 1953M 7,62 mm-es K-I-es könnyű géppisztoly, a 7,62 mm-es korszerüsített 1943M (KGK) géppuska fémjelzi.

KULCSSZAVAK: Kucher József, Danuvia Fegyver- és Lőszergyár Részvénytársaság, Haditechnikai Intézet, Budapesti Múszaki Egyetem Hadmérnöki Kar

Nyugalmazott rendőrfőtanácsos, ORCID: 0000-0002-9059-0822 ket. Tehetsége, szorgalma itt is segítette, 1962 és 1963 között a vállalat főmérnöke, majd nyugdíjazásáig a nagyüzem főkonstruktőre volt. Lőfegyverszerkesztő munkásságát a rendszeresített 1953M 7,62 mm-es K-I-es könnyü géppisztoly, a 7,62 mm-es korszerűsített 1943M (KGK) géppuska fémjelzi. A neves szakember 1976-ban, Budapesten hunyt el. A honvédelmi miniszter a 90/1992. számú parancsában az 1953. évi lefokozási parancsot hatályon kívül helyezte, egyben előléptette posztumusz ezredessé. Kucher József mk. ezredes a magyar fegyverkonstruktőrök virtuális arcképcsarnokának egyik kiemelkedő helyét foglalja el.

\section{FORRÁSOK}

1. Központi Irattár (továbbiakban: KI): 57601 Kucher József;

2. KI: Honvédelmi Minisztérium Rehabilitációs Bizottság 40/542/1992. számú igazolása;

3. Állambiztonsági Szolgálatok Történelmi Levéltára: 3.1.9. V-106468

4. Szellemi Tulajdon Nemzeti Hivatal, Elektronikus kutatás: HU122239, HU127695;

5. Dr. Bartha Tibor mk ezredes: Kucher József; Haditechnika 2000/4. sz. 40. o.;

6. Dr. Hajdú Ferenc: A K-5 jelű 45 mm-es gyalogsági páncélromboló fegyver fejlesztésének története, Haditechnika 2011/2. sz., 51-53. o.;

7. Pap Péter: Kucher József mérnök ezredes; A Hadtörténeti Múzeum értesítője Budapest 2014/14. sz. 84-130. o.;

8. Pap Péter: Az 1952M 45 mm-es páncéltörő löveg; Haditechnika 2013/6. sz. 60-64. o. és 2014/1 63-67. o.

\section{JEGYZETEK}

1 KI: 26. o. és 1950. január 18-án felfektetett „Személyi adatlap” 9. o. 2 Hadtörténelmi Levéltár (továbbiakban HL): 1949/T. 44. doboz, 1. őrzési egység 423. o.

3 HL: Magyar Néphadsereg 1950/T 893. doboz 2. őrzési egység 147-151. o.

4 HL: Magyar Néphadsereg 1950/T 893. doboz 1. őrzési egység 44-46. o.

ABSTRACT: József Kucher, a firearms designer, worked at the Danuvia Armory and Ammunition Factory Company between 1936 and 1945. In 1948 he was placed in Institute of Military Technology In 1953, he was sentenced to death by hanging in a show trial, which judgement was changed to life imprisonment. After 1956, he found work at the Danuvia Machine Tool Factory. His activity in the field of fire arm design is hallmarked by the 1939M $9 \mathrm{~mm}$ and K-I submachine guns, the K-II machine gun, the K-III infantry armour destroyer, the 1953M $7.62 \mathrm{~mm} \mathrm{~K}-1$ light submachine gun, and the $7.62 \mathrm{~mm}$ modernized 1943M (KGK) machine gun.

KEY WORDS: József Kucher, Danuvia Armory and Ammunition Factory Company, Institute of Military Technology, Military Engineering Faculty of the Budapest University of Technology 